\title{
RESIDÊNCIA PEDAGÓGICA NA UFT/ARRAIAS: OFICINA DE CONFECÇÃO DE INSTRUMENTOS MUSICAIS EM UMA ESCOLA DO CAMPO
}

UFT / Arraias pedagogical residence: musical instruments workshop in a field school

La Residencia pedagógica UFT / Arraias: taller de instrumentos musicales en una escuela del campo

Aparecida de Jesus Soares Pereira ${ }^{* 1}$, Vera Lúcia dos Santos Almeida Ribeiro ${ }^{1}$, Dayane Romualdo Bispo ${ }^{1}$, Rosinilton Domingos Correia ${ }^{1}$, Sulene Reges da Cunha ${ }^{1}$

${ }^{1}$ Laboratório de Educação Musical, Curso de Licenciatura em Educação do Campo, Universidade Federal do

Tocantins, Arraias, Brasil.

*Correspondência: Curso de Licenciatura em Educação do Campo, Universidade Federal do Tocantins - UFT, Campus Professor Dr. Sérgio Jacintho Leonor, Av. Juraíldes de Sena e Abreu, Setor Buritizinho/ sala 10 - Bloco Bala, Arraias - Tocantins, Brasil.CEP:77.330-000.e-mail: cida.soares@uft.edu.br

Artigo recebido em 09/04/2020 aprovado em 16/04/2020 publicado em 18/04/2020.

\section{INTRODUÇÃO}

O intuito deste trabalho é demonstrar a importância do Programa Residência Pedagógica (PRP) da Universidade Federal do Tocantins em Arraias na inter-relação e inserção do ensino musical no âmbito educacional de uma Escola de Educação Básica do campo por meio do PRP, destacando assim aspectos positivos e negativos enfrentados em efetivação.

O Programa Residência Pedagógica (PRP) se faz importante pois o mesmo é uma ação implementada pela Coordenação de Aperfeiçoamento de Pessoal de Nível Superior (CAPES) direcionado aos discentes dos cursos das Instituições de Ensino Superior IES (públicas e privadas), visando à vivência e a experimentação de situações concretas do cotidiano escolar e da sala de aula em consonância com Estágio Curricular dos cursos de licenciatura. O Programa Residência Pedagógica possibilita a formação de profissionais- que sejam capazes de investigar, pensar, compreender e recriar a realidade que se encontra em profundas transformações, e sua contribuição diante desses desafios é que além da implantação do ensino de música nas escolas do campo, é que também possa contribuir para a formação de professores que atuam ministrando aulas de Artes, abordando os conteúdos Artes Visuais e Música, e neste caso especificamente a música. A partir de trabalhos científicos em nível de monografia no âmbito do curso percebe-se que na região sudeste do Tocantins, nas escolas pesquisadas, não se encontrou professores que atuam na área das Artes com habilitação específica na área de Música.

Diante desta realidade, Silva e Pereira argumentam que, "faz-se necessário haver conhecimento específico para a alfabetização através da linguagem musical para que a mesma aconteça de forma sistematizada" (SILVA; PEREIRA, 2017, p. 338).

Desse modo, o subprojeto RP "O ensino de música nas escolas do campo" do Curso Licenciatura em Educação do Campo, Códigos e Linguagens: Artes Visuais e Música - Campus de Arraias proporciona ao residente o aperfeiçoamento da prática docente, contribuindo para a formação profissional na área de Artes Visuais e Música, e consequentemente no desenvolvimento de habilidades práticas, especificamente para o ensino de música nas escolas de educação básica campesina. 


\section{METODOLOGIAS E MATERIAIS}

Ao iniciar as atividades foi preciso que os residentes obtivessem contato com o núcleo escolar pedagógico para a apresentação, obter informações e conhecimento sobre o funcionamento da instituição escolar e suas práticas, focando principalmente nas aulas de Artes, com o objetivo de observar como acontece o processo de ensino e aprendizagem em música. Os residentes fizeram análises de documentos estruturais da escola, tais como: Projeto Político Pedagógico (PPP), estrutura curricular e conteúdos programáticos distribuídos pela Secretaria de Estado de Educação - SEDUC e pelas Secretaria Municipal de Assistência Social - SEMAS de cada município.

É notório que mesmo com os desafios de lecionar em uma área de conhecimento onde os professores não possuem formação, as aulas acontecem no sentido de cumprir os conteúdos do currículo escolar.

Na observação também foi detectado que a escola enfatiza a cultura regional, tendo em vista que a maioria dos alunos são remanescentes de comunidades Quilombolas (Tocantins e Goiás). A Unidade de Ensino (UE) por sua vez valoriza os saberes culturais e os insere no cotidiano escolar, tendo como exemplo, os eventos realizados pela escola onde são inseridas músicas, danças e outras manifestações culturais.

Para Silva; Pereira (2017, p. 186) "A Educação Musical consiste basicamente em desenvolver no indivíduo a percepção musical, a criatividade e a sensibilidade musical". Assim, no sentido de desenvolver tais habilidades nos alunos da escola parceira no RP optou-se por desenvolver um projeto de confecção de instrumentos musicais a partir de materiais reutilizáveis. Neste sentido, foi construído por residentes e alunos da escola, diversos instrumentos musicais como: violão artesanal e vários instrumentos de percussão que foram utilizados como recurso didático-pedagógico nas aulas de música para desenvolver a criatividade musical, culminando com apresentação pública para a comunidade escolar. Ao final das atividades do RP os instrumentos confeccionados pelos residentes e alunos foram doados para escola.

Diante disso é possível afirmar que a inserção dos residentes do Curso Educação do Campo se faz importante no cotidiano escolar, pois através dos conhecimentos adquiridos na academia possibilita e facilita a troca de saberes durante as atividades que o RP proporciona.

É importante salientar que estas experiências vivenciadas foram de fundamental importância para a formação acadêmica destes residentes, pois os mesmos vivenciaram a realidade do contexto educacional.

A presença da música na escola pode ser estudada a partir dos mais variados tipos de fontes, mediantes entrevistas com diretores, inspetores e coordenadores escolares, professores, pais e alunos. (GONÇALVES, 2009, p.167).

É notória que a unidade escolar faz o possível para se adequar à cultura e à realidade dos alunos, mas infelizmente fatores negativos como a falta de estrutura da UE, polivalência do corpo docente, inexistência de professores com formação específica na área de Artes, a pequena carga horária semanal destinada para as aulas de Artes e a ausência do ensino sistematizado de música dentro do componente curricular Artes, são alguns fatores que podem comprometer a formação integral dos educandos que estarão desprovidos de criatividade, coordenação motora, concentração e outros aspectos que as Artes proporcionam. Dessa forma, Pereira; Silva (2017), destacam que

o conhecimento torna-se superficial nas linguagens artísticas, com uma proposta metodológica de certa forma ineficaz para uma formação generalista que não será capaz de 
dominar as especificidades de cada linguagem artística. (PEREIRA; SILVA, 2017, p. 180)

À vista disso é explícito o descaso, e a falta de conhecimento dos órgãos competentes perante a realidade da UE e dos seus docentes, situação que impossibilita cada vez mais a busca pela consolidação do ensino musical na educação básica nas escolas do campo.

\section{RESULTADOS E DISCUSSÃO}

É notório que o RP contribuiu como um fator importante em se tratando da implantação do ensino musical nas escolas do campo, pois o mesmo propõe oportunidades da inserção do ensino de música nas escolas e proporciona aos residentes aplicarem os conhecimentos teóricos/práticos adquiridos na academia, adequando-os metodologicamente para aplica-los na regência nas escolas.

\section{CONCLUSÃO}

Conclui-se que o Programa RP adquire importância pela parceria que assume a Universidade e instituições básicas de ensino em um único objetivo: fomentar a formação inicial e continuada de profissionais de magistério e programas da educação, especificamente da educação musical nas escolas básicas do campo, pois contribui para que os residentes tenham o aperfeiçoamento, experiência no processo de ensino-aprendizagem, ao agir em parceria com o Estágio Curricular Supervisionado proporcionando ao acadêmico mais conhecimento e vivência em sua prática. Dessa forma, o RP torna-se um trabalho colaborativo envolvendo e integrando a Instituição de Ensino Superior em parceria com o Estágio e as Escolas de Educação Básica, estabelecendo assim, o tripé: Universidade, Estágio e Escolas.

\section{AGRADECIMENTOS}

À CAPES pelo incentivo financeiro. À UFT por tornar possível a realização do Programa Residência Pedagógica. Também pelo uso de laboratórios e/ou empréstimo de equipamentos. Ao Curso de Licenciatura em Educação do Campo da UFT. Às Escolas parceiras e Secretaria de Educação.

Todos os autores declararam não haver qualquer potencial conflito de interesses referente a este artigo.

\section{REFERÊNCIAS}

GONÇALVES Lilia Neves. A aula de música na escola: reflexões a partir do filme Mudança de hábito 2: mais loucuras no convênio. In: SOUZA, Jusamara (org.) Aprender e ensinar música no Cotidiano. Porto Alegre. Sulina, 2009. 287. (Coleção Músicas) $2^{\mathrm{a}}$ edição.

SILVA, Waldir Pereira da; PEREIRA, Aparecida de Jesus Soares. Educação Musical na Educação do Campo: metodologias alternativas em uma abordagem contemporânea. Revista de estúdios e investigación en psicología y educación eissn: 2386-7418, 2017, Vol. Extr., No. 04.

SILVA, Waldir Pereira da; PEREIRA, Aparecida de Jesus Soares. Anais I seminário internacional e IV seminário nacional de estudos e pesquisas sobre a educação do campo. 2017.UFSCar-São Carlos, SP. ISSN: 2526-7965. 